\title{
Analisis Nilai Tambah Pengolahan Belut Menjadi Keripik Belut (Studi Kasus) di Desa Kedu Kecamatan Buay Madang Timur Kabupaten OKU Timur
}

\author{
Imam Sulaiman \\ Sekolah Tinggi Ilmu Pertanian Belitang \\ Jln.Kampus Pertanian No.3 Belitang Kab.OKU Timur Prov.Sumatera Selatan. \\ Email : djameel.sulaiman@gmail.com
}

\begin{abstract}
Abstrak
Tujuan dari penelitian ini adalah untuk: 1) mengetahui besarnya pendapatan yang diperoleh dari pengolahan belut menjadi keripik belut di Desa Kedu Kecamatan Buay Madang Timur Kabupaten OKU Timur, 2) mengetahui besarnya nilai tambah yang diperoleh dari pengolahan belut menjadi keripik belut di Desa Kedu Kecamatan Buay Madang Timur Kabupaten OKU Timur. Hasil penelitian menunjukkan bahwa biaya produksi dalam pengolahan belut menjadi keripik belut yang ada di Desa Kedu Kecamatan Buay Madang Timur adalah sebesar Rp 738.380/PP. Pendapatan dalam usaha pengolahan belut menjadi keripik belut di Desa Kedu adalah Rp 611,620/PP Sedangkan nilai tambah yang dihasilkan dalam usaha tersebut adalah Rp 709,120/ PP dan 78,781/ Kg. Usaha pengolahan belut menjadi keripik belut menguntungkan dan layak untuk dikembangkan di Desa Kedu Kecamatan Buay Madang Timur dengan beberapa indikatornya adalah RC ratio sebesar 1,83. BEP Harga sebesar Rp 82.042 /Kg, BEP Produksi sebesar 1 kg, BEP Penerimaan sebesar Rp 72,680.
\end{abstract}

Kata Kunci : Value-Added, Budidaya Belut, Agroindustri.

\section{PENDAHULUAN}

\section{A. Latar Belakang}

Perkembangan perikanan di Indonesia pada saat ini telah mampu memperlihatkan identitasnya, memberikan sumbangan dalam pembangunan perekonomian bangsa. Secara keseluruhan perikanan mempunyai peran dan posisi yang penting dalam pemenuhan kebutuhan gizi protein, kesempatan kerja, penerimaan devisa dan pengembangan wilayah (Baharsyah, 2002).

Pengolahan hasil perikanan merupakan kegiatan industri yang menciptakan nilai tambah bagi komoditi perikanan melalui produk olahan dalam bentuk setengah jadi maupun barang jadi yang bahan bakunya berasal dari perikanan. Usaha-usaha pengolahan hasil perikanan yang mengarah pada kegiatan industri yaitu pengolahan hasil perikanan menjadi bahan makanan. Salah satu produk perikanan olahan yang dapat diolah yaitu keripik belut.

Belut (monopetrus albus zuieuw) merupakan salah satu sumber lauk pauk yang memiliki kandungan protein tinggi. Daging belut sendiri mempunyai nilai kandungan gizi yang baik untuk tubuh. Keripik belut merupakan salah satu pangan fungsional dimana memiliki kadar protein yang tinggi, juga memiliki rasa yang khas sehingga banyak digemari masyarakat.

Menurut Nurudin (2007), belut merupakan ikan konsumsi air tawar yang banyak digemari. Hampir 50 $\%$ dari kandungan tubuhnya mengandung protein hewani yang sangat baik untuk kesehatan, dan dapat di lihat pada tabel di bawah ini:

Tabel 1. Kandungan gizi belut

\begin{tabular}{cccc}
\hline Zat Gizi & Belut & Telur & Daging sapi \\
\hline Kalori & 303 & 162 & 207 \\
Protein & $14 \mathrm{~g}$ & $12,8 \mathrm{~g}$ & $18,8 \mathrm{~g}$
\end{tabular}

\begin{tabular}{cccc} 
Lemak & $27 \mathrm{~g}$ & $11,5 \mathrm{~g}$ & $14 \mathrm{~g}$ \\
Karbohidrat & $0 \mathrm{~g}$ & $0,7 \mathrm{~g}$ & $0 \mathrm{~g}$ \\
Fospor & $200 \mathrm{mg}$ & $180 \mathrm{mg}$ & $170 \mathrm{mg}$ \\
Kalsium & $20 \mathrm{mg}$ & $54 \mathrm{mg}$ & $11 \mathrm{mg}$ \\
Zat Besi & $20 \mathrm{mg}$ & $2,7 \mathrm{mg}$ & $2,8 \mathrm{mg}$ \\
Vitamin A & $1.600 \mathrm{mg}$ & $900 \mathrm{SL}$ & $30 \mathrm{mg}$ \\
Vitamin B1 & $0,1 \mathrm{mg}$ & $0,1 \mathrm{mg}$ & $0,08 \mathrm{mg}$ \\
Vitamin C & $2 \mathrm{mg}$ & $0 \mathrm{mg}$ & $0,08 \mathrm{mg}$ \\
Air & $58 \mathrm{~g}$ & $74 \mathrm{~g}$ & $66 \mathrm{mg}$ \\
\hline
\end{tabular}

Menurut Tunjungsari (2007), keripik merupakan salah satu produk makanan hasil diverifikasi sebagai makanan ringan (snack food), yang bersifat kering dan renyah (crispy). Sifat renyah pada keripik akan hilang bilang produk tersebut menyerap air. Produk ini banyak digemari oleh masyarakat dari berbagai kalangan karena rasanya yang enak, renyah, praktis, mudah dibawa dan disimpan, memiliki cita rasa yang gurih serta dapat dinikmati setiap saat sebagai makanan selingan, keripik bisa dibuat dari berbagai macam bahan. Pada dasarnya keripik merupakan jenis makanan ringan yang berbentuk lembaran tipis, kemudian digoreng atau dipanggang, sehingga mempunyai tekstur yang renyah. Salah satu keistimewaan keripik ini adalah dapat disajikan dalam aneka bentuk dan cita rasa. Menurut Azahari (2007), selain dikonsumsi sebagai makanan, belut juga kerap diolah menjadi jenis makanan ringan yang lezat seperti keripik belut. Keripik belut berbahan baku, belut tepung beras serta bawang merah dan bawang putih dan ketumbar. Keripik selama ini menjanjikan keuntungan, karena mengingat disukai lapisan masyarakat.

Tabel 2. komposisi kimia keripik belut:

Komponen

Jumlah (\%) 


\begin{tabular}{lc} 
Kadar air & 3,67 \\
kadar protein & 28,96 \\
kadar lemak & 0,29 \\
\hline
\end{tabular}

Sumber:Azhari, 2007.

Proses penggorengan dilakukan degan memasukkan belut kedalam minyak panas, minyak goreng bertindak sebagai media pemanas dan berkontribusi terhadap tekstur dan rasa makanan yang digoreng. Proses menggoreng pada prinsipnya adalah memasak atau mengeringkan bahan sehingga produk yang dihasilkan lebih layak dikonsumsi atau lebih kering, tetapi penggorengan terlalu lama juga berakibat penurunan nilai gizi pada bahan makanan tersebut, dalam proses penggorengan usahakan belut dalam keadaan kering serta menggunakan minyak yang bermutu baik,serta gunakan suhu yang sesuai, berkisar $100-180^{\circ} \mathrm{C}$ sehingga menghasilkan produk yang bermutu tinggi.

Untuk meningkatkan nilai tambah belut dapat diolah menjadi keripik belut, untuk memenuhi kebutuhan keripik belut di OKU Timur terdapat home industri yang mengolahnya.

\section{B. Rumusan Masalah}

Adapun rumusan dalam penelitian adalah :

1. Berapa pendapatan yang diperoleh dari pengolahan belut menjadi keripik belut di Desa Kedu Kecamatan Buay Madang Timur Kabupaten OKU Timur?

2. Berapa besar nilai tambah yang diperoleh dari pengolahan belut menjadi keripik belut di Desa Kedu Kecamatan Buay Madang Timur Kabupaten OKU Timur?

\section{Tujuan dan Kegunaan Penelitian}

Adapun tujuan dari penelitian ini adalah:

1. Untuk mengetahui besarnya pendapatan yang diperoleh dari pengolahan belut menjadi keripik belut di Desa Kedu Kecamatan Buay Madang Timur Kabupaten OKU Timur?

2. Untuk mengetahui besarnya nilai tambah yang diperoleh dari pengolahan belut menjadi keripik belut di Desa Kedu Kecamatan Buay Madang Timur Kabupaten OKU Timur?

\section{Hipotesis}

Hipotesis dari rumusan masalah dapat dikemukakan

1. Bahwa biaya produksi usaha pengolahan belut menjadi keripik belut di Desa Kedu Kecamatan Buay Madang Timur Kabupaten OKU Timur lebih rendah dari pada penerimaan sehingga diperoleh pendapatan.

2. Bahwa usaha pengolahan belut menjadi keripik belut di Desa Kedu Kecamatan Buay Madang
Timur Kabupaten OKU Timur akan memperoleh nilai tambah.

\section{KERANGKA TEORITIS}

\section{A. Tinjauan Pustaka}

\section{B. Model Pendekatan}

Model pendekatan yang digunakan dalam penelitian ini adalah model pendekatan secara diagramatis yaitu sebagai berikut :

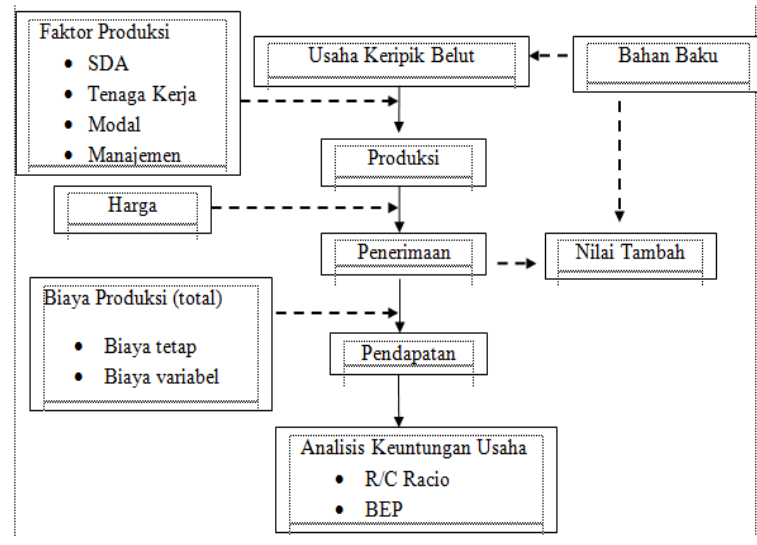

Keterangan :

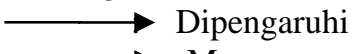

$----\rightarrow$ Mempengaruhi

\section{Pembatasan Masalah}

1. Responden adalah pelaku home industri keripik belut yang berada di Desa Kedu Kecamatan Buay Madang Timur Kabupaten Oku Timur.

2. Belut adalah bahan baku utama untuk pengolahan keripik belut.

3. Keripik belut adalah jenis makanan yang berbentuk cemilan renyah yang diproses dengan penggorengan dengan bahan baku belut dan bahan lain.

4. Biaya tetap adalah biaya yang penggunaannya tidak habis dalam sekali proses produksi dan biaya besar kecilnya tidak dipengaruhi oleh jumblah produksi(Rp/PP).

5. Biaya variabel adalah biaya yang jumlahnya tergantung dari besarnya jumblah produksi serta habis dalam satu kali proses produksi (Rp/PP).

6. Biaya produksi adalah total biaya yang dikeluarkan dalam satu kali proses produksi yang meliputi biaya tetap dan biaya variabel(Rp/PP).

7. Produksi adalah produk yang dihasilkan oleh responden berupa berupa keripik belut dengan satuan $(\mathrm{Kg})$.

8. Harga adalah nilai jual dari kripik belut yang ditetapkan oleh responden pada saat penilitian $(\mathrm{Rp} / \mathrm{Kg})$ 
9. Penerimaan adalah jumlah dari hasil produksi $(\mathrm{Kg})$, yang diperoleh home industri dikali dengan harga $(\mathrm{Rp})$, pada saat penelitian $\mathrm{Rp} / \mathrm{PP}$ ).

10. Pendapatan adalah selisih antara pentimaan dengan biaya produksi yang dikeluarkan selama proses produksi berlangsung.

11. Pasar tradisional adalah tempat bertemunya penjua dan pembeli serta ditandai dengan adanya transaksi penjual pembeli secara langsung dan biasanya ada proses tawar menawar.

12. Pengecer adalah seseorang yang menjalankan penjualan barang langsung ke konsumen ahir untuk penggunaan pribadi dan bukan bisnis.

13. Nilai tambah adalah selisih antara nilai output yang dihasilkan dengan biaya antara bahan baku $(\mathrm{Rp} / \mathrm{Kg})$.

14. Biaya antara adalah biaya yang dikeluarkan dalam proses produksi seperti bahan baku dan input lainnya kecuali tenaga kerja keluarga

\section{METODE PENELITIAN}

\section{A. Tempat dan Waktu}

Penelitian ini telah dilaksanakan di Desa Kedu Kecamatan Buay Madang Timur Kabupaten OKU Timur. Penentuan lokasi dilakukan secara sengaja(purposive) dengan pertimbangan bahwa di Desa Kedu terdapat industri rumah tangga pengolahan belut menjadi keripik belut. Sedangkan penelitian telah dilaksanakan pada Bulan Agustus sampai dengan November 2019.

\section{B. Metode Penelitian dan Pengambilan sampel}

Metode yang digunakan dalam penelitian ini adalah studi kasus, menurut Bimo Walgito (2010), menyatakan bahwa studi kasus merupakan suatu metode untuk menyelidiki atau mempelajari suatu kejadian mengenai perseorangan atau suatu usaha.

Metode penarikan contoh dalam penelitian ini adalah dengan menggunakan metode survey, yaitu penelitian yang sumber data dan informasi utamanya diperoleh dari responden sebagai sampel penelitian dengan menggunakan kuisioner sebagai alat pengumpulan data. Sample dalam penelitian ini yaitu home industri yang berada di Desa Kedu Kecamatan Buay Madang Timur Kabupaten OKU Timur.

\section{Metode Pengumpulan Data}

Metode pengumpulan data dilakukan yaitu dengan cara observasi langsung yang dilakukan dengan cara pengambilan data primer dan data sekunder :

1. Pengambilan data primer adalah data yang diperoleh dengan melakukan pengamatan secara langsung ke lokasi penelitian serta wawancara langsung menggunakan daftar pertanyaan (kuesioner) kepada pelaku usaha pengolahan belut menjadi keripik belut di Desa Kedu Kecamatan Buay Madang Timur Kabupaten OKU Timur.
2. Pengambilan data sekunder diperoleh dari lembaga-lembaga yang terkait meliputi keadaan umum wilayah penelitian, data yang berasal dari buku perpustakaan dan jurnal.

\section{Metode Pengolahan Data}

Data yang diperoleh dari lapangan dianalisa mengunakan analisis matematis. Untuk menjawab hipotesis yang pertama, menggunakan beberapa rumus sebagai berikut :

1. Untuk menghitung biaya produksi (Soekartawi, 2002), dengan rumus :

$\mathrm{TC}=\mathrm{FC}+\mathrm{VC}$

Keterangan :

$\mathrm{TC}=$ Total Cost $/$ Biaya Produksi (Rp)

$\mathrm{FC}=$ Fixed Cost $/$ Biaya Tetap $(\mathrm{Rp})$

$\mathrm{VC}=$ Variable Cost/ Biaya Tidak Tetap (Rp)

2. Untuk menghitung penerimaan (Soekartawi, 2002), digunakan rumus :

$\mathrm{TR}=\mathrm{Y} \times \mathrm{Py}$.

Keterangan :

$\mathrm{TR}=$ Total Revenue/ Total Penerimaan ( $\mathrm{Rp})$

$\mathrm{Y}=$ Output Produksi/ Hasil Produksi $(\mathrm{Kg})$

Py = Harga Jual (Rp/ Kg)

3. Untuk menghitung pendapatan (Soekartawi, 2002), digunakan rumus :

$\mathrm{I}=\mathrm{TR}-\mathrm{TC}$.

Keterangan :

$\mathrm{I}=$ Income/ Pendapatan (Rp)

$\mathrm{TR}=$ Total Revenue/ Penerimaan $(\mathrm{Rp})$

$\mathrm{TC}=$ Total Cost $/$ Total Biaya Produksi (Rp)

Untuk menjawab hipotesis yang kedua, dapat menggunakan rumus untuk mengetahui nilai tambah (Yudi, 2010) dari pengolahan keripik belut dengan rumus :

4. Untuk menghitung nilai tambah menggunakan rumus :

$\mathrm{AV}=\mathrm{TR}-\mathrm{IC}$

Keterangan :

$\mathrm{AV}=$ Added Value/ Nilai Tambah

$\mathrm{TR}=$ Total Revenue/ TotalPenerimaan

$\mathrm{IC}=$ Intermediate Cost/ Biaya Antara (biaya produksi - biaya tenaga kerja )

5. Untuk mengetahui untung tidaknya usaha pengolahan belut menjadi keripik belut menggunakan rumus:

a. $\mathrm{RC}$ Ratio $=\frac{T R}{T C}$

Dimana :

RC Ratio : Rasio perbandingan antara penerimaan dan total biaya

$\mathrm{TC}:$ Total cost / total biaya

$\mathrm{TR}:$ Total revenue / total penerimaan

Keterangan :

Jika nilai $\mathrm{R} / \mathrm{C}>1 \rightarrow$ maka usaha pengolahan keripik belut menguntungkan.

Jika nilai $\mathrm{R} / \mathrm{C}=1 \rightarrow$ maka usaha pengolahan keripik belut mengalami titik impas.

Jika nilai $\mathrm{R} / \mathrm{C}<1 \rightarrow$ maka usaha pengolahan keripik belut merugi. 
ISSN : 2598-0521

b. Titik impas atau Break Event Point (BEP), menurut (Suratiyah, 2006) sebagai berikut:

1). BEP harga adalah harga terendah dimana sebuah usaha berada pada titik impas, dengan rumus :

BEP harga $\quad=\frac{T C}{Y}$

2). BEP Produk adalah produksi terendah dimana sebuah usaha berada pada titik impas, dengan rumus :

BEP produk $=\frac{F C}{P-A V C}$

3). BEP Penerimaan adalah penerimaan terendah dimana sebuah usaha berada pada titik impas, dengan rumus :

BEP penerimaan $=\frac{F C}{1-\frac{V C}{S}}$

Dimana :

FC : Fixed Cost / biaya tetap (Rp)

VC : Variable Cost / biaya variabel per unit (Rp)

TC : Total Cost / biaya total (Rp)

$\mathrm{P}$ : Price / harga $(\mathrm{Rp} / \mathrm{kg})$

$\mathrm{Y}$ : Yield / jumlah produk $(\mathrm{Kg})$

$\mathrm{S}:$ Penerimaan (Nilai produksi = jumlah produksi)

AVC : Average Variable Cost (Biaya per unit = Biaya Variabel dibagi total produksi).

\section{HASIL DAN PEMBAHASAN}

\section{Analisis Usaha Pengolahan Belut Menjadi Keripik} $\underline{\text { Belut }}$

Dalam menganalisis usaha pengolahan belut menjadi keripik belut di Desa Kedu dapat dilakukan dengan menghitung besarnya biaya produksi, penerimaan, pendapatan,nilai tamabah R/C Ratio dan BEP (Harga, Penerimaan, Produksi).

Tabel 3. Uraian Penerimaan dan Pendaapatan

No

Uraian
Per Proses

Satuan

$\begin{array}{clcc}1 & \text { Kebutuhan Belut } & 10 & \mathrm{Kg} \\ 2 & \text { Produksi Keripik Belut } & 9 & \mathrm{Kg}\end{array}$

\begin{tabular}{clrc}
3 & Harga Jual Keripik Belut & 150000 & $\mathrm{Rp} / \mathrm{Kg}$ \\
4 & Penerimaan & 1350000 & $\mathrm{Rp} / \mathrm{pp}$ \\
5 & Biaya Produksi & 738,380 & $\mathrm{Rp} / \mathrm{Pp}$ \\
6 & Pendapatan & 611,620 & $\mathrm{RP} / \mathrm{Pp}$ \\
\hline
\end{tabular}

Sumber: Olahan Data Primer, 2019.

Untuk dapat lebih jelas mengetahui analisis dalam usaha tersebut dapat diketahui dalam uraian berikut :

1. Produksi Usaha Pengolahan Belut menjadi Keripik $\underline{\text { Belut }}$

Menurut responden dalam satu kali proses produksi pengolahan belut menjadi keripik belut di Desa Kedu Kecamatan Buay Madang Timur membutuhkan waktu sehari, namun dalam satu bulan mereka hanya bisa melakukan 3 kali proses produksi dikarnakan jumlah pasokan belut mentah masih sangat terbatas. Dalam satu kali proses produksi responden hanya mampu mengolah $10 \mathrm{Kg}$ belut mentah yang berasal dari pengepul belut yang ada dibeberapa wilayah, menurut responden proses produksi pengolahan keripik belut di Desa kedu Kecamatan Buay Madang Timur terdiri dari beberapa kegiatan teknis yang diantaranya sebagai berikut :

a. Menyiapkan bahan baku utama berupa belut segar, menurut responden mereka mampu mengolah belut yang segar dari pengepul sebanyak $10 \mathrm{Kg}$ dengan harga rata - rata $\mathrm{Rp} 30.000 / \mathrm{Kg}$. Untuk kriteria belutnya sendiri, tidak ada kriteria khusus karna sedikit susah mencari belut di alam,sehingga yang tersedia di pengepul saja yang dibuat untuk bahan baku. Selain itu reponden juga menggunakan bahan lain berupa tepung rosebrand, minyak goreng, telur, air bersih, bumbu dapur serta yang lainnya.

b. Menyiapkan alat - alat pendukung proses penggorengan belut seperti wajan, sutil, ember, tungku, irek, serok, kayu bakar serta yang lainnya.

c. melakukan pembersihan belut. Merupakan kegiatan memotong atau menyayat dan membuang isi dari dalam perut belut menggunakan pisau. Sebelum disayat belut dilumuri dengan abu gosok yang bertujuan untuk menghilangkan lendir, sehingga ketika dipegang belut tersebut tidak licin lagi. Setelah itu belut disayat satu persatu menggunakan pisau yang tajam agar dapat memudahkan proses pengeluaran isi atau organ dalam seperti usus dari bagian perut sampai ujung dari ekornya.

d. belut yang sudah disayat lalu dikumpulkan dalam bak besar untuk dilakukan pencucian. Pencucian dilakukan menggunakan air sumur sampai bersih dari darah atau kotoran yang menempel pada daging belut, setelah itu belut ditiriskan sampai kandungan air hilang.

e. Pembuatan adonan dilakukan dengan cara pencampuran tepung rosebrand dengan air lalu ditambahkan garam secukupnya dan penyedap rasa, serta tambahkan telur dan tambahkan bumbu 
halus, Sekali produksi pembuatan adonan dilakukan sebanyak tiga kali dengan komposisi, 3 ons bawang merang dan bawang putih, sedikit ketumbar serta 5 butir telur dan $2 \mathrm{~kg}$ tepung rosebrand.

f. penggorengan, dengan cara memanaskan minyak sampai mendidih lalu masukkan belut satu persatu dengan rapi tunggu sampai belut berwarna coklat kekuningan kira - kira 15 - 20 menit lalu angkat dan tiriskan.

2. Biaya Produksi Usaha Pengolahan Belut Menjadi Keripik Belut

Biaya produksi ( total cost) yang ada dalam usaha pengolahan belut menjadi keripik belut terdiri dari biaya tetap dan biaya variabel. biaya produksi dalam usaha tersebut adalah Rp 738,380/ proses produsi. Biaya tetap merupakan biaya yang tidak habis dalam satu kali proses produksi, seperti biaya sewa tempat usaha dan penyusutan alat, dengan biaya sewa tempat usaha sebesar Rp 69.444/ proses produksi, serta biaya penyusutan alat sebesar Rp 3,236/ proses produksi. Rincian biaya penyusutan dapat dilihat dalam tabel berikut :

Tabel 4. Biaya Penyusutan Alat

\begin{tabular}{|c|c|c|c|c|c|c|c|c|}
\hline $\mathrm{N}_{0}$ & Uraian & $\begin{array}{c}\text { Belut } \\
\text { (Kg/Proses) }\end{array}$ & $\begin{array}{c}\text { Tenaga Kerja } \\
\text { (Orang) }\end{array}$ & $\begin{array}{l}\text { Jumlah } \\
\text { (Jam) }\end{array}$ & $\begin{array}{c}\text { Upah } \\
(\mathrm{Rp} / \mathrm{HOK})\end{array}$ & $\begin{array}{l}\text { Jumlah } \\
\text { (Hari) }\end{array}$ & $\begin{array}{c}\text { Biaya } \\
\text { (RPpiproses) }\end{array}$ & $\begin{array}{c}\text { Biaya } \\
\text { (Rp/Bulan) }\end{array}$ \\
\hline 1 & Pembersihan Kotoran & 10 & 2 & 2 & 60,000 & 0.50 & 30,000 & 360,000 \\
\hline 2 & Pembuatan Bumbu & 10 & 1 & 0.5 & 60,000 & 0.06 & 3,50 & 45,000 \\
\hline 3 & Pencampuran Adonan & 10 & 1 & 0.5 & 60,000 & 0.06 & 3,750 & 45,000 \\
\hline 4 & Pengoverngan & 10 & 2 & 3 & 60,000 & 0.75 & 45,000 & 540,000 \\
\hline 5 & Pengemasan & 10 & 2 & 1 & 60,000 & 0.25 & 15,000 & 180,000 \\
\hline Total & & & & & & & 97,500 & $1,170,000$ \\
\hline
\end{tabular}

Sumber: Olahan Data Primer, 2019.

Biaya variabel (variable cost) merupakan biaya yang dapat habis dalam satu kali proses produksi pengolahan belut menjadi keripik belut, seperti nilai bahan baku dan tenaga kerja, yang meliputi nilai bahan baku sebesar Rp 568.200/ PP dan nilai tenaga kerja sebesar Rp 97.500/PP.

Tabel 5. Biaya Variabel

\begin{tabular}{cccc}
\hline \multirow{2}{*}{ No } & \multirow{2}{*}{ Uraian } & \multicolumn{2}{c}{ Biaya Variabel } \\
& & Rp/Proses & Rp/Bulan \\
\hline 1 & Biaya Bahan Baku & 568,200 & $6,818,400$ \\
2 & Biaya Tenaga Kerja & 97,500 & $1,170,000$ \\
\hline \multirow{2}{*}{ Total } & & 665,700 & $7,988,400$ \\
\hline
\end{tabular}

Sumber: Olahan Data Primer, 2019.

3. Penerimaan dan Pendapatan Usaha Pengolahan

Belut menjadi Keripik Belut

Menurut Suratiyah (2006), penerimaan merupakan nilai produk total yang dapat dihasilkan dalam sebuah usaha dan pada jarak tertentu. Sedangkan pendapatan merupakan selisih antara jumlah penerimaan dan seluruh biaya produksi. Adapun uraian dari penerimaan dan pendapatan yang diperoleh responden dalam usaha pengolahan belut menjadi keripik belut di Desa Kedu Kecamatan Buay Madang Timur dalam satu kali proses produksi dapat dilihat pada table berikut :

Tabel 6. Penerimaan dan Pendapatan

No Uraian Per Proses Satuan

Sumber: Olahan Data Primer, 2019.

\section{Nilai Tambah Usaha Pengolahan Belut Menjadi Keripik Belut}

Nilai tambah adalah selisih antara nilai komoditi yang mendapat perlakuan pada tahap tertentu dikurangi dengan nilai korbanan yang digunakan selama proses produksi berlangsung. Nilai tambah yang dapat dihasilkan dalam usaha pengolahan belut menjadi keripik belut di Desa Kedu adalah Rp. 709.120 per proses produksi. Berdasarkan hal tersebut maka usaha pengolahan belut menjadi keripik belut di Desa Kedu menguntungkan.

Tabel 7. Nilai Tambah

\begin{tabular}{|c|c|c|c|c|c|}
\hline \multirow{2}{*}{ No } & \multirow{2}{*}{$\begin{array}{c}\text { Hasil } \\
\text { Produks } \\
\text { i } \\
(\mathrm{Rp} / \mathrm{PP})\end{array}$} & \multirow{2}{*}{$\begin{array}{c}\text { penerimaa } \\
\mathbf{n} \\
(\mathbf{R p} / \mathbf{P P})\end{array}$} & \multirow{2}{*}{$\begin{array}{c}\text { Biaya } \\
\text { Antara } \\
\text { (Rp/pp } \\
\text { ) }\end{array}$} & \multicolumn{2}{|c|}{ Nilai Tambah } \\
\hline & & & & $\begin{array}{c}(\mathbf{R p} / \mathbf{P p} \\
)\end{array}$ & $\begin{array}{c}\mathrm{Rp} / \mathrm{Kg} \\
)\end{array}$ \\
\hline 1 & 9 & 1350000 & $\begin{array}{c}640,88 \\
0\end{array}$ & 709,120 & 78,791 \\
\hline
\end{tabular}

Sumber: Olahan Data Primer, 2019.

5. R/C Ratio Usaha Pengolahan Belut Menjadi $\underline{\text { Keripik Belut }}$

Nilai dari R/C Ratio dalam usaha pengolahan belut menjadi keripik belut di Desa Kedu Kecamatan Buay Madang Timur adalah 1,83 yang menunjukan bahwa nilai R/C Ratio > 1 yang berarti bahwa usaha tersebut menguntungkan dan layak untuk dikembangkan karena dalam Rp. 1 biaya yang dikeluarkan dalam 
usaha tersebut maka responden memperoleh penerimaan Rp. 1,83.

6. BEP (Break Event Point) Usaha Pe ngolahan Belut Menjadi Keripik Belut

BEP (Break Event Point) yang ada dalam usaha pengolahan belut menjadi keripik belut meliputi BEP Harga, BEP Produksi, BEP Penerimaan. BEP Harga keripik belut sebesar Rp. 82,042 per kg yang berarti bahwa jika keripik belut dijual dengan harga tersebut maka responden tidak memperoleh untung atau rugi. Hal ini disebabkan BEP Harga menunjukan harga pokok keripik belut per $\mathrm{kg}$.

BEP Produksi dalam pengolahan keripik belut adalah $1 \mathrm{~kg}$ yang berarti bahwa apabila responden mampu memproduksi dan menjual keripik belut sebanyak $1, \mathrm{~kg}$ sehingga responden tidak memperoleh untung atau rugi (impas). Sedangkan BEP Penerimaan dalam usaha keripik belut tersebut adalah Rp. 72,680. untuk itu apabila responden menerima penerimaan dari usaha tersebut sebesar Rp. 72,680 maka responden tidak memperoleh untung atau rugi.

\section{KESIMPULAN DAN SARAN}

\section{A. Kesimpulan}

Berdasarkan hasil dan pembahasan dari penelitian yang telah dilaksanakan, maka dapat diambil kesimpulan sebagai brikut :

1. Biaya produksi dalam pengolahan belut menjadi keripik belut yang ada di Desa Kedu Kecamatan Buay Madang Timur adalah sebesar Rp 738.380/PP.

2. Pendapatan dalam usaha pengolahan belut menjadi keripik belut di Desa Kedu adalah Rp 611,620/PP Sedangkan nilai tambah yang dihasilkan dalam usaha tersebut adalah Rp 709,120/ PP dan 78,781/ $\mathrm{Kg}$.

3. Usaha pengolahan belut menjadi keripik belut menguntungkan dan layak untuk dikembangkan di Desa Kedu Kecamatan Buay Madang Timur dengan beberapa indikatornya adalah $\mathrm{RC}$ ratio sebesar 1,83. BEP Harga sebesar Rp 82.042 /Kg, BEP Produksi sebesar $1 \mathrm{~kg}$, BEP Penerimaan sebesar Rp 72,680.

\section{B. SARAN}

1. Hendaknya pengelola pembuatan keripik belut agar tetap menjaga dan memperhatikan kualitas produk .

2. Untuk memenuhi kebutuhan bahan baku hendaknya pengelola pembuatan keripik belut memperbanyak mitra petani pencari belut atau memulai dengan budidaya belut.

\section{DAFTAR PUSTAKA}

Baharsyah. 2002. Pengembangan Pengembangan Wilayah Perikanan di Indonesia. Departemen Pertanian. Jakarta.
Firdaus, M. 2007. Manajemen Agribisnis. Bumi Aksara. Jakarta.

Hafsah, MJ. 2003. Bisnis Belut Indonesia. Jakarta: Pustaka Sinar Harapan.

Hasyim, A.I. 2012. Pengantar Tataniaga Pertanian. Buku Kuliah Fakultas Pertaniaan Universitas Lampung. Bandar Lampung.

Kartasapoerta. 2005. Pengantar Ekonomi Produksi. Bina Angkasa. Jakarta.

Malisi, S. 2016. Analisis Nilai Tambah Pengolahan Produksi Hasil Pertanian Bandung.

Nazir, M. 2010. Metode Penelitian. Ghalia Indonesia. Bogor.

Saanin, H. 2006. Taksonomi dan Kunci Identifikasi Ikan. Binacipta. Jakarta.

Sjarkowi, F. 2010 manajemen pembangunan agribisnis. CV Baldad Grafiti Press Palembang.

Sjarkowi, F. \& Marwan Sufri 2005. Manajemen Agribisnis. Baldad Graffiti Pres. Palembang.

Soeharjo dan Pantong. 2003. Sendi-sendi Pokok Usahatani. Departemen Ilmu Sosial Ekonomi Pertanian. IPB. Bogor.

Senior. 2007. Si Licin Belut Kuatkan Tulang. http://www cybermed. Cbn. Net.id. (19 Mei 2017).

Soekartawi. 2001. Prinsip Dasar Komunikasi Pertanian. UI Press. Jakarta.

Soekartawi. 2002. Analisis Usahatani. Universitas Indonesia (UI Pres). Jakarta.

Sundoro. Rms. 2003. Belut: Budidaya dan Pemanfaatannya. Jakarta : Agromedia Pustaka.

Tunjungsari. 2007. Pemanfaatan ikan sapu-sapu dalam pembuatan keripik ikan. Institut Pertanian Bogor.

Winarno, F.G. 2007. Pengantar Ilmu Teknologi Pangan. PT. Gramedia. Jakarta.

Yudi, A, B. 2010. Sistem Agribisnis Terintegrasi Hulu - Hilir. CV Muara Indah. Bandung. 